\title{
УKPAÏHCbKA ЛITEPATYPA
}

УДК 821.161.2Шевч.09

DOI https://doi.org/10.32838/2663-6069/2020.2-3/27

Бондарєва Н. О.

Київський національний університет імені Тараса Шевченка

\section{«ЧИГИРИНСЬКИЙ КОБЗАР І ГАЙДАМАКИ» ТАРАСА ШЕВЧЕНКА: ПРОБЛЕМИ СИНХРОННОЇ РЕЦЕПЦІЇ}

У статті описано і проаналізовано всі відомі відгуки і згадки про «Чигиринський Кобзар і Гайдамаки» 1844 р. Т. Шевченка. Їх нечисленність пояснюється тим, що це видання не містило жодного нового твору, а текст поеми «Гайдамаки» навіть не було наново набрано тільки механічно зброшуровано з другим виданням «Кобзаря». Однак доволі обмежена рещепиія збірки 1844 р. становила важливий момент в осмисленні Шевченкової творчості в контексті розвитку літературно-критичної думки середини 1840-х рр. незадовго до арешту поета, коли на десять років запанувала майже повна мовчанка щодо особи і доробку заслания. Два відгуки у журналах «Отечественные записки» $i$ «Маяк»- -унаочнили існування двох течій у тогочасній російській критиці: представники однієї ставилися до поезї Шевченка $і$ загалом украйнського письменства глузливо-вороже, маскуючи несприйнятття і нерозуміння мови пласкими дотепами та недоречною іронією, репрезентанти другої розглядали творчість поета як складник загальноімперського дискурсу, а тому не могли визнати окремішньої української літератури. Обидва погляди в історичній перспективі виявилися цілком хибними, проте вони на десятиліття визначили вектор сприйняття Шевченкової постаті в російській критиці.

Відкритим залишено питання атрибуиї рекламного оголошення в додатку до «Московских ведомостей». Можна тільки констатувати кричущий брак аргументів на користь авторства О. Бодянського, яке обстоює В. Мельниченко. Сучасний стан джерел поки не дає змоги з високою точністю з'ясувати авторів інших двох відгуків. Варто приєднатися до припущення Г. Грабовича, щзо нотатка в «Отечественных записках» належить В. Бєлінському. Водночас зберігають своє значення навіть геть лапідарні згадки про «Чигиринський Кобзар», як-от I. Вагилевича 1848 р., П. Сфименка та О. Ротчева (обидві 1861 р.).

Ключові слова: речепція, атрибучія, поетична збірка, літературна критика, анонім.

Постановка проблеми. В останні роки помітного поширення набуває автономне вивчення синхронної рецепції тих Шевченкових видань, які порівняно 3 «Кобзарем» 1840 р. цілком природно привертали суттєво менше уваги. Заглиблення в матеріали прижиттєвої критики дає змогу відстежити закономірності тогочасного сприйняття Шевченкової творчості, виявити, з одного боку, причини схвалення, а 3 другого - негації та голослівної критики.

Аналіз останніх досліджень і публікацій. Прикладом таких студій недавнього часу можуть слугувати статті О. Бороня про оцінку в російській критиці окремих видань поем «Тризна» i «Гамалія» ([6, с. 264-271; 7, 58-62]; під назвою «Російська критика $1840-\mathrm{x}$ років про поеми «Тризна» і «Гамалія»» увійшли до збірника статей [5, с. 245-254]). Своєю чергою ми розробляли подібну проблематику на матеріалі Шевченкового «Букваря южнорусского» [2, с. 48-55]. Дослідження в цьому аспекті істотно пожвавилися після виходу грунтовного зведення матеріалів критики прижиттєвої і першого року після смерті поета в упорядкуванні того ж О. Бороня і М. Назаренка $[16 ; 17]$.

Постановка завдання. Мета статті - виявити й описати всі прижиттєві відгуки на друге видання «Кобзаря», охарактеризувати їх зміст і тональність, окреслити значущість в осмисленні Шевченкової творчості загалом.

Виклад основного матеріалу. Досі не вивченим залишається сприйняття другого видання Шевченкового «Кобзаря», відомого під назвою «Чигиринський Кобзар і Гайдамаки» 1844 р. [23], тоді як текстологічні аспекти цієї збірки досліджено належною мірою, переважно в роботах 
В. Бородіна. У бібліографії шевченкознавчої літератури вдалося виявити тільки одну спеціальну працю про «Чигиринський Кобзар» [13, с. 135139], інспіровану відзначенням століття від часу його появи у світ. Серйозною перепоною автономному вивченню рецепції «Чигиринського Кобзаря» тривалий час був той факт, що відгуків на видання з'явилося вкрай мало: як вважалося, всього лише дві короткі репліки, про які йтиметься далі. Водночас завдяки зусиллям В. Мельниченка в науковий обіг уведено не відоме доти розлоге оголошення про плановану появу видання, опубліковане в додатку до газети «Московские ведомости» [18], саме 3 нього слід починати відлік публічної реакції на друге видання «Кобзаря».

Як відомо, Шевченко не брав до уваги «Чигиринський Кобзар», адже, готуючи у 1847 р. нове видання своїх творів (не здійснене), розпочав передмову до нього словами: «Випускаю оце в люде другого «Кобзаря»...» [21, с. 207]. Історію появи «Чигиринського Кобзаря» свого часу з'ясував ще В. Бородін на основі архівних і маловідомих джерел [4, с. 29-33]. Вимушено уклавши 3 книгарем I. Лисенковим угоду про продаж літературних прав на перший «Кобзар» $\mathrm{i}$ «Гайдамаки», Шевченко не зважив на неї, коли після повернення із заслання готував нове видання своїх поезій. У шостому томі Повного зібрання творів Шевченка у 12-ти томах у розділі «Документи, складені Т. Шевченком або за його участю» помилково не вміщено два майже ідентичні за змістом Шевченкові написи від 8 лютого 1843 р. на примірнику «Кобзаря» 1840 р. і «Гайдамаків» 1841 р. про продаж права на видання I. Лисенкову. Перший напис відомий тільки за публікацією в газеті «Судебный вестник» 1867 р., натомість зберігся відповідний примірник поеми. Прикрий недогляд виправлено в розділі «Уточнення й доповнення (до томів 1-6)» у 12-му томі зібрання [22, с. 498, 515]. Шевченко зробив у тексті деяких творів кілька виправлень (див.: [20, с. 430-431, 438-439, 446]), змінено й послідовність розташування творів («Катерину» перенесено в кінець збірки, тоді як у першому виданні вона містилася після «Перебенді» й перед «Тополею»).

Варто також нагадати, що спершу видання, як свідчить реєстр цензурного комітету, мало вийти під тією ж назвою - «Кобзар» (цензурний дозвіл отримано 19 лютого 1843 р.) [4, с. 83]. І. Лисенков одержав від Шевченка 800 примірників нерозпроданого накладу «Гайдамаків» і одразу ж розмістив у газетах оголошення про продаж поеми у своїй книгарні, причому за ціною, істотно нижчою від початкової (замість 5 рублів асигнаціями лише 75 копійок сріблом, тобто 2 рублі 62 з половиною копійки асигнаціями): «ГАЙДАМАКИ. Поэма T. Шевченка. Стихотворение на малороссийском языке. 130 страниц. Цена 75 к. сер., с пересылкою во все города России» [14, с. 152]. Тоді, очевидно, I. Лисенков і вирішив об'єднати під спільним титулом «Чигиринський Кобзар і Гайдамаки» нове видання поезії та механічно припасовані нерозпродані примірники поеми «Гайдамаки». Отже, назва належить видавцеві.

Головним джерелом інформації про синхронну рецепцію «Чигиринського Кобзаря» слугує, зрозуміло, перший том згаданого зведення «Тарас Шевченко в критиці», водночас було перевірено й кілька інших джерел. Зокрема, В. Дорошенко серед рецензій на видання називає публікації 1844 р. у «Литературной газете» (№ 19) та В. Тіунського (колективний псевдонім) у червневому числі журналу «Москвитянин» [19, с. 30]. Перегляд обох названих видань переконав у тому, що бібліограф помилився: рецензій на «Кобзар» 1844 р. тут не вміщено. Помилку, мабуть, зумовлено тим, що у вказаному номері «Литературной газеты» надруковано відгуки на окремі видання «Гамалії» i «Тризны», а у «Москвитянине» В. Тіунського на «Гамалію».

Хронологічно першим стало вже згадане оголошення в «Прибавлениях к № 19-му «Московских відомостей»») від 12 лютого 1844 р. про очікувану появу видання. У «Прибавлениях» традиційно друкувалися різноманітні рекламні оголошення. В. Мельниченко його автором вважає О. Бодянського: «....перед нами чимала публікація про поетичний збірник Шевченка «Чигиринський Кобзар і Гайдамаки», навіть ширше - про творчість Тараса Григоровича взагалі, як сказали б сьогодні, московська піар-акція на славу молодого українського генія. Хто міг це тоді зробити так упевнено й переконливо? Не сумніваюся, то був Осип Бодянський, який досконало знав творчість Шевченка і всі національні нюанси, 3 ним пов'язані. Виявлення цієї статті тим цінніше, що досі в бібліографії друкованих праць Бодянського 1844 рік не було представлено жодною публікацією» (виділення автора. - Н. Б.) [11, с. 178]. Уперше текст оголошення дослідник опублікував, супроводивши реальним коментарем, ще у 2007 p. в газеті «Слово Просвіти» [10, с. 8-9]. Насправді, крім висловлення переконаності, жодних посутніх аргументів він не навів. Шевченко в той час, 12-19 лютого 1844 р., перебував у Москві, де вперше зустрівся з О. Бодянським [9, с. 99], однак 
немає доказів пов’язаності його приїзду з появою цієї публікації.

Звернімося до тексту рекламного оголошення. Розлогий проспект майбутнього видання розпочинається доволі точним бібліографічним описом, але без вказівки на кількість сторінок. Головна мета - повідомити, де саме можна замовити книжку, яка ще не надійшла у продаж: «В СанктПетербурге в книжном магазине И. Т. Лисенкова, под №№ 3 и 4-м, в доме Пажеского ЕГО ИМПЕРАТОРСКОГО ВЕЛИЧЕСТВА Корпуса, продаётся книга, поступившая в печать новым изданием и в непродолжительном времени окончится печатанием на веленевой бумаге...» [16, с. 160]. Коротко схарактеризовано автора: «...T. Г. Шевченко ещё молодой человек, природный сын Южной России, воспитан в С.-Петербурге в Академии художеств и владеет дарованием прекрасного живописца. В детстве своём, наслушавшись в Малороссии об кобзаре-импровизаторе, передал нам его думы в прекрасных, мелодических стихах. Его думы дышат самым нежным, меланхолическим чувством и воспоминаниями о старине» [16, с. 161-162]. Далі наведено перелік назв уміщених у збірці творів із перекладом за необхідності російською мовою, подано кілька чималих цитат. Завершується оголошення не менш важливою для книготорговця інформацією, виділеною курсивом: «Цена в обёртке с двумя виньетками, изображсающими вид Днепра и поле давно минувших битв, полагается самая умеренная, на веленевой бумаге ПЯТЬ РУБЛЕЙ АССИГНАЦИЯМИ и с пересылкою во все города России, по выходе же оной из печати, иногородным за эту иену не уступается, а должны будут прилагать за почтовую пересылку особо. И потому заблаговременно желающие получить благоволят адресовать свои требования по вышеозначенному адресу в книжный магазин ЛИСЕНКОВА, в С.-Петербург, из которого и получат по отпечатании с первою почтою» [16, с. 163]. Тобто автор оголошення прагне забезпечити виданню передплату, намагаючись привабити покупців нижчою ціною порівняно з тією, яка буде після виходу книжки друком, адже тоді за пересилку треба буде платити додатково.

Хіба міг О. Бодянський, щойно познайомившись із Шевченком, виписувати в газетному оголошенні умови продажу видання, яке насправді ще й не починало друкуватися? Наклад виготовлено лише влітку 1844 р., квиток на випуск у світ видано 17 серпня того ж року [4, с. 32]. Звідки міг О. Бодянський знати його точну назву? Та й Шев- ченкові було цілком байдуже до цієї книжки, адже він продав літературні права на свої твори, отримавши гонорар від І. Лисенкова, а тому не мав жодної зацікавленості в комерційному успіху видання i, як уже сказано, взагалі не брав його до уваги. Крім того, дуже сумнівно, щоб Шевченко погодився назвати вісім творів «Кобзаря» «поемою» поряд із «Гайдамаками». Ймовірніше, що оголошення складено за вказівками І. Лисенкова в Петербурзі та надіслано до редакції московської газети. Гіпотеза В. Мельниченка має існувати тільки як сміливе припущення, не більше, бо підгрунтя для неї немає.

Наступним став анонімний відгук у жовтневому числі «Отечественных записок» (цензурний дозвіл 30 вересня 1844 р.), який задля повноти аналізу слід навести повністю: «Благодаря неутомимой деятельности г. Шевченка, малороссийская литература процветает себе, да и только! Если, несмотря на то, она совершенно неизвестна в Великороссии, так это не потому, чтоб малороссийская литература в богатстве и достоинстве своих произведений уступала, например, французской, а потому, что в Великороссии пока ещё мало распространено знание иностранных языков. Помилуйте, может ли малороссийская литература быть ниже какой бы то ни было литературы, когда для неё трудятся такие поэты, как г. Шевченко? - То-то талант! Что́ ваш Пушкин!» [16, с. 173]. Стиль цього короткого відгуку нагадує глузливу манеру рецензій В. Бєлінського на видання української літератури, зокрема поему «Гайдамаки». Г. Грабович переконаний: «За стилістикою, темпераментом, ідеями, кусячою іронією і не в останню чергу фактом, що він і далі керував тоді в «Отечественных записках» відділом критики - це чистої води Бєлінський» $[8$, c. 62$]$.

Проблема з'ясування авторства непідписаних у журналі матеріалів, як описує іiі В. Боград, дуже складна. Відомо, що В. Бєлінський, як правило, рецензував за деякими винятками петербурзькі видання, а випущені у Москві - відповідно московські співробітники журналу, хоча іноді траплялися відхилення від цієї усталеної процедури. В. Боград наголошує на тому, що за поодинокими винятками імена авторів, які працювали 3 В. Бєлінським над відгуками про петербурзьку книжкову продукцію, невідомі [1, с. 29]. Як показує досвід, пише дослідник, з'ясовувати авторство нотаток за їх змістом і стилем треба з граничною обережністю [1, с. 27]. До того ж треба пам'ятати, що вся редакція намагалася писати в одному 
ключі, тому індивідуальний стиль у невеликих замітках затирався. Авторство нотатки встановити поки не пощастило, але вона справді може належати В. Бєлінському, адже всі матеріали «Библиографической хроники» в цьому номері журналу, імена авторів яких з'ясовано, підпадають під правило про розподіл книжок за місцем видання між В. Бєлінським і московськими співробітниками за винятком відгуку О. Галахова на випущений у Петербурзі навчальний курс словесності В. Плаксіна. Це сталося, мабуть, тому, що О. Галахов у цьому ж номері рецензував московське видання теорії словесності [1, с. 247-249].

Анонімний критик намагається принизити українську літературу, знущально-іронічно зіставляючи іiї з французькою, а далі - Шевченка 3 О. Пушкіним, демонструючи в такий спосіб нібито цілковиту непорівнюваність обох літератур і названих постатей. Мимоволі автор відгуку висловив цілком правильну і своєчасну думку, що українська мова - іноземна щодо російської. Те, що журнальному оглядачу видавалося дотепним жартом, було абсолютною правдою. Натомість у тодішній російській журналістиці панувала думка, що українська - лише місцевий діалект російської, тоді як ні критики, зокрема В. Бєлінський, ні цензори української насправді геть не розуміли. Анонім виявив історичну прозірливість: нині вже нікого не здивуєш паралелями між українським і французьким письменством, а Шевченка часто називають в одному ряду з О. Пушкіним серед національних поетів слов'янства.

Зовсім іншу тональність і спрямування має ще коротший відгук у 34-й книжці консервативного «Маяка» 1844 р., відомого прихильністю до української літератури: «Читатели «Маяка» так уже хорошо знакомы с нашим необыкновенным певцом Малороссии, что нет надобности повторять исчисление красот двух его поэм, заученных наизусть всею Малороссией. Издание это гораздо исправнее первого со стороны правописания, и за это будут благодарны Издателю все многочисленные почитатели г. Шевченки» [16, с. 173]. Правопис «Гайдамаків», звісно, не було виправлено, адже це те саме перше видання поеми 1841 року, зброшуроване 3 «Кобзарем» 1844 р. під однією обкладинкою [16, с. 649], про що вже йшлося. Зауваження рецензента свідчить, що він тільки поверхово ознайомився 3 виданням, не дочитавши, мабуть, до поеми «Гайдамаки», набраної недбало. Впадає в око, що критик констатує добру обізнаність публіки з іменем і творчістю Шевченка, зумовлену надзвичайною популярністю першого «Кобзаря». Саме тому I. Лисенков i розраховував на успіх другого видання. Оглядач «Маяка» не випадково називає співця України «нашим», тобто не розмежовує українську i російську літературу, послідовно утверджуючи загальноімперський дискурс. Епітети на кшталт «необыкновенный» щодо поетичного обдарування Шевченка не повинні вводити в оману: журнал убачав в українському письменстві лише обласний варіант великоросійського.

У першому томі зведення «Тарас Шевченко в критиці» не вміщено ще одне повідомлення 3 журналу «Современник» [12, с. 364]. Про нього згадано в бібліографії 1963 р. [15, с. 13]. Пояснення такому рішенню упорядників О. Бороня і М. Назаренка просте: «Современник» обмежився тільки суто бібліографічним описом видання, тоді як до корпусу матеріалів «не заведено публікацій, які містять самі лише безоцінкові згадки про Шевченка, як-от бібліографічні повідомлення в російській пресі про появу у світ його книжок...» [16, c. 607].

Цим вичерпуються літературно-критичні відгуки на «Кобзар» 1844 р. Втім, задля повноти картини не можна оминути коротких, але доволі показових згадок про нього. У 1848 р. І. Вагилевич у продовженні нарису історії української літератури «Zamitki o ruskoj literaturi» у дев'ятому числі часопису «Dnewnyk ruskij», що виходив у підавстрійському Львові, побіжно згадав «Чигиринський Кобзар», приписавши його назву також першому виданню: «Т. S z e w c z e ń k o znakomytyj poeta, izdał swoi werszi pod nadpysom: «Czyhyryńskij Kobzar'» (Petersb. 1840, wtor. izd. 1844)» (розрядка автора. - Н. Б.) [16, с. 199]. Заувага I. Вагилевича важлива тим, що з'явилася у пресі за межами Російської імперії. Незадовго до смерті Шевченка у закінченні публікації «Украинская литературная летопись» у «Полтавских губернских ведомостях» від 22 лютого 1861 р. П. Єфименко констатував, що у «Кобзар» 1860 р. увійшли поезії, опубліковані в «Кобзарі» 1844 р. [16, с. 602]. Згадано про «Чигиринський Кобзар і Гайдамаки» невдовзі після смерті поета в публікації О. Ротчева «Т. Г. Шевченко» в часописі «Русский художественный листок» від 20 березня 1861 p. [17, с. 78]. Таким чином, розглянуто буквально всі відомі натепер прижиттєві згадки про «Чигиринський Кобзар». Водночас залишається ймовірність того, що колись буде виявлено ще невідомі оголошення про друге видання «Кобзаря», як це доводить приклад пошукової роботи В. Мельниченка. 
Насамкінець не можна не згадати той важливий факт, що саме примірник «Чигиринського Кобзаря і Гайдамаків» 1844 р. поруч із примірником «Кобзаря» 1860 р. став робочим для Шевченка, коли він у 1859-1860 рр. редагував власні твори. Нині це одне 3 важливих джерел тексту його поезій, а в попередніх академічних виданнях він слугував навіть для деяких творів джерелом основного тексту. Нині цей унікальний примірник зберігається у відділі рукописних фондів і текстології Інституту літератури ім. Т. Г. Шевченка НАН України (фонд 1, од. зб. 76).

Висновки і пропозиції. Описано і проаналізовано всі відомі відгуки і згадки про «Чигиринський Кобзар і Гайдамаки» 1844 р. Їх нечисленність пояснюється тим, що видання не містило жодного нового твору, а текст поеми «Гайдамаки» навіть не було наново набрано - тільки механічно зброшуровано 3 другим виданням «Кобзаря». Однак доволі обмежена рецепція видання становила важливий момент осмислення Шевченкової творчості в контексті розвитку літературно-критичної думки середини 1840-х рр. незадовго до арешту поета, коли на десять років запанувала майже повна мовчанка щодо особи і доробку засланця (див.: [3, с. 18-21]). Два відгуки - в «Отечественных записках» $\mathrm{i}$ «Маяке» - унаочнили існування двох течій у тогочасній російській критиці: представники однієї ставилися до поезії Шевченка і зага- лом українського письменства глузливо-вороже, маскуючи несприйняття і нерозуміння мови пласкими дотепами та недоречною іронією, репрезентанти другої розглядали творчість поета як складник загальноімперського дискурсу, а тому не могли визнати окремішньої української літератури. Обидва погляди в історичній перспективі виявилися цілком хибними, проте вони на десятиліття визначили вектор сприйняття Шевченкової постаті в російській критиці.

Відкритим залишається питання атрибуції рекламного оголошення в додатку до «Московских ведомостей». Можна тільки констатувати кричущий брак аргументів на користь авторства О. Бодянського. Сучасний стан джерел також поки не дає змоги з високою точністю з'ясувати авторів інших двох відгуків. Варто приєднатися до припущення Г. Грабовича, що нотатка в «Отечественных записках» належить В. Бєлінському. Зберігають своє значення навіть геть лапідарні згадки, як-от I. Вагилевича, П. Єфименка, О. Ротчева.

До подальших перспективних завдань у напрямі дослідження прижиттєвої рецепції Шевченкової творчості, серед іншого і конкретних його видань, належить фронтальний перегляд комплектів тогочасних російських газет, які зберігаються у книгосховищах Москви і Санкт-Петербурга. Дослідників ще можуть чекати несподівані знахідки і відкриття.

\section{Список літератури:}

1. Боград В. Э. Журнал «Отечественные записки», 1839-1848: указатель содержания. Москва : Книга, $1985.688 \mathrm{c}$.

2. Бондарєва Н. О. «Букварь южнорусский» Тараса Шевченка в синхронній рецепції (1862 рік). Літературознавчі студіï. Київ : Київський університет, 2016. Вип. 50. С. 48-55.

3. Бондарєва Н. О. Крізь заборони і мовчання: згадки про творчість Тараса Шевченка у період його заслання. Science and Education a New Dimension. Philology. Budapest, 2017. V (35). Issue 125. P. $18-21$.

4. Бородін В. С. Т. Г. Шевченко і царська цензура. Дослідження та документи. 1840-1862 роки. Київ : Наук. думка, 1969. 166 с.

5. Боронь О. Поет і його проза: генеза, семантика і рецепція Шевченкової творчости : збірка статей. Київ : Критика, 2015. С. 245-254.

6. Боронь О. Російська критика 1840-х років про поему Шевченка «Тризна». Шевченкознавчі студії : 3б. наук. праць. Київ : Київський університет, 2011. Вип. 14. С. 264-271.

7. Боронь О. Поема Тараса Шевченка «Гамалія» в оцінці російської критики (1844 рік). Тарас Шевченко $i$ сьогодення : матеріали Другої Всеукраїнської науково-практичної конференції. Сімферополь, 2012. С. 58-62.

8. Грабович Г. Шевченкові «Гайдамаки»: поема і критика. Київ : Критика, 2013. 360 с.

9. Жур П. В. Труди і дні Кобзаря: літопис життя і творчості Т. Г. Шевченка. Київ : Дніпро, 2003. 520 с.

10. Мельниченко В. Подарунок Осипа Бодянського до 30-річчя Тараса Шевченка. Слово Просвіти. 2007. 20-26 вересня. № 38. С. 8-9.

11. Мельниченко В. Ю. Тарас Шевченко в Москві. Київ : Либідь, 2009. 740 с.

12. Новые издания. Современник. 1844. Т. 36. № 12. С. 364.

13. Пільгук І. Сто років «Чигиринського Кобзаря». Украӥнська література. 1944. № 2/3. С. $135-139$.

14. Северная пчела. 1843. 17 февраля. № 38. С. 152.

15. Т. Г. Шевченко: Бібліографія літератури про життя і творчість. 1839-1959 / склали І. 3. Бойко та ін. Київ : Вид-во АН УРСР, 1963. Т. 1 (1839-1916). 
16. Тарас Шевченко в критиці. Київ : Критика, 2013. Т. І: Прижиттєва критика (1839-1861) / заг. ред. Г. Грабовича ; упоряд. О. Бороня, М. Назаренко ; комент. О. Бороня та ін. 804 с.

17. Тарас Шевченко в критиці. Київ : Критика, 2016. Т. II: Посмертна критика (1861) / заг. ред. Г. Грабовича ; упоряд. О. Бороня, М. Назаренко; комент. О. Бороня, М. Назаренко, О. Федорук. 806 с.

18. Чигиринский Кобзарь и Гайдамаки. Прибавления к № 19 «Московских ведомостей». 1844. 12 февраля. С. 194.

19. Шевченко Т. Повне видання творів : у 14 т. 2-ге вид., доп. Чикаго : Видавництво М. Денисюка, 1961. T. XIV: Покажчик видань Шевченкових творів. Першодруки й окремі видання та список літератури про них ; Зібрав і впорядкував В. Дорошенко. 506 с.

20. Шевченко Т. Г. Повне зібрання творів : у 12 т. Київ : Наук. думка, 2001. Т. 1: Поезія 1837-1847. 781 с.

21. Шевченко Т. Г. Повне зібрання творів: у 12 т. Київ : Наук. думка, 2003. Т. 5: Щоденник. Автобіографія. Статті. Археологічні нотатки. «Букварь южнорусский». Записи народної творчості. 495 с.

22. Шевченко Т. Г. Повне зібрання творів : у 12 т. Київ : Наук. думка, 2014. Т. 12: Літопис життя і творчості Тараса Шевченка (за Петром Журом). Документи, покажчики. 543 с.

23. Шевченко Т. Чигиринский Кобзарь и Гайдамаки. Две поэмы на малороссийском языке. Новое издание. С картинкою. Санкт-Петербург : В тип. Х. Гинце, 1844. 131 с.

\section{Bondarieva N. O. «KOBZAR FROM CHYHYRYN AND HAYDAMAKY» BY TARAS SHEVCHENKO: SYNCHRONOUS REPETITIONS PROBLEMS}

All known feedbacks and references regarding "Kobzar from Chyhyryn and Haydamaky» 1844 by T. Shevchenko are described and analyzed in this article. The reason, that there are only so few of them, can be explained by the fact, that this edition did not contain any new works, and the text of the poem "Haydamaky" was not even typed anew - it was only mechanically put together with the other edition of "Kobzar». But rather limited perception of the 1844 collection played an important role in understanding Shevchenko's works in the context of all the critical literary thinking development in the middle 1840-s, shortly before the poet was arrested and almost complete silence took over regarding the personality and works of the outlaw for the next ten years. Two feedbacks - in «The National Notes» and «Mayak»-demonstrated existence of two streams in Russian critique of that time: the representatives of one of them had mocking and hostile attitude towards Shevchenko's poetry and Ukrainian literature in general, trying to cover their non-perception and lack of understanding the language with jokes, that were not funny, and inappropriate irony, while the representatives of the other one regarded the poet's works as part of overall imperial discourse, and, for this reason, they could not recognize independence of Ukrainian literature. In historical prospect, both options proved to be wrong, even though they determined for the decades the vector of how the personality of Shevchenko was perceived in Russian critique.

The question of attribution of an advertisement in the addition to «Moscow vedomosti» is still open. One can only ascertain very obvious lack of the facts to prove, that $O$. Badianskiy was an author of $i$, as mentioned by $V$. Melnychenko. Contemporary state of the sources of information does not allow us to prove, who the authors of the other two feedbacks were. G. Hrabovych's assumption, that the reference in "The National Notes» belongs to V. Belinkiy, is worth considering as a true one. At the same time, even totally lapidary links to "Kobzar from Chyhyryn» are meaningful, for example, the ones by I. Vahylevych in 1848, P. Efremenko and O. Rotchev (both from 1861).

Key words: perception, attribution, collection of poetry, literary critique, anonym. 